\title{
Satellite tracking reveals the migration route and wintering area of the Middle East population of Critically Endangered northern bald ibis Geronticus eremita
}

\author{
Jeremy A. Lindsell, Gianluca Serra, Lubomir Peške, Mahmoud S. A b d ullah \\ GhaZy al Qaim, Ahmed Kanani and Mengistu Wondafrash
}

\begin{abstract}
Since its discovery in 2002 the small colony of northern bald ibis Geronticus eremita in the central Syrian desert remains at perilously low numbers, despite good productivity and some protection at their breeding grounds. The Syrian birds are migratory and return rates of young birds appear to have been poor but because the migration route and wintering sites were unknown little could be done to address any problems away from Syria. Satellite tracking of three adult birds in 2006-2007 has shown they migrate through Jordan, Saudi Arabia and Yemen to the central highlands of Ethiopia. The three tagged birds and one other adult were found at the wintering site but none of the nine younger birds that also left Syria were with them. At least four birds wintered elsewhere because they returned to the colony the following spring. The return migration followed the western shore of the Red Sea through Eritrea to Sudan before crossing the Red Sea into Saudi Arabia, then northwards to Syria. The adults appeared to be at low risk on the wintering site although we recommend protection. Threats along the migration route now need to be assessed and mitigated, and further effort made to determine the movements of subadults and young birds.
\end{abstract}

Keywords Argos, Geronticus eremita, migration, northern bald ibis, PTT, Syria, telemetry.

\section{Introduction}

7 he northern bald ibis Geronticus eremita is one of only I three Critically Endangered birds whose breeding range is confined to the Western Palearctic (BirdLife International, 2000; IUCN, 2008). Until recently the only known breeding colonies were along a small stretch of

Jeremy A. Lindsell The RSPB, Sandy, UK

GiANluCA SERRA (Corresponding author) Via Giambologna 20, 50132 Florence, Italy. E-mail abunug@gianlucaserra.com

Lubomir Peš́e Prague, Czech Republic.

Mahmoud S. Abdullah, Ghazy al Qaim and Ahmed Kanani Deser Commission, Palmyra, Syria.

Mengistu Wondafrash Ethiopian Wildlife and Natural History Society, Addis Ababa, Ethiopia.

Received 30 October 2007. Revision requested 22 January 2008. Accepted 7 April 2008. coastline in Morocco now subject to intensive conservation management. A Middle Eastern population was thought extinct since 1989 (Arihan, 1998), and extinct in Syria since the late 1920s (Safriel, 1980), part of a broad long-term decline in this species (Kumerloeve, 1984). Unlike the relatively sedentary Moroccan birds, the eastern population was migratory (Hirsch, 1979) but the migration routes and wintering sites were unknown. The discovery of a colony of northern bald ibises in Syria in 2002 (Serra et al., 2003) confirmed the survival of this migratory population. The Syrian birds arrive in the breeding area in February and depart in July. Knowledge of the migration routes and wintering sites is crucial for the successful conservation of the eastern population.

The Syrian colony had only 2-3 breeding pairs in 20022006 and, although breeding productivity has been high (Serra et al., 2007a, in press), comparing favourably with Moroccan colonies (Bowden et al., 2003), the colony has not increased in size. Twenty offspring fledged in 20022006 but only four subadults returned and there was only one recruit into the breeding population (Serra et al., in press). Even allowing for delayed recruitment (Bowden et al., 2003), return rates in the Syrian population seem low, suggesting that juvenile or subadult survival on migration or in the wintering areas is poor. Adult survival rates are unknown but at least one breeding adult has died each winter during 2002-2006, whereas only one adult mortality has been detected at the breeding grounds.

Many historical records exist of ibises presumably on migration or at their wintering grounds (Collar \& Stuart, 1985; Welch \& Welch, 2004). The last 2oth century record for each country in the region is given in Table 1. Sightings continued for 8 years after the last known wild birds were taken into captivity in Turkey in 1989. From 1997 to 2002 ibises were breeding, migrating and wintering undetected in the region, raising the possibility that other small relict colonies may remain undetected. We considered that satellite tracking ibises could lead to the discovery of other ibis colonies, provide clues to the poor recruitment rate, and lead to conservation actions to improve overwinter survival. Understanding the migration and wintering behaviour could help explain the observations in Syria that subadults return long after the adults have arrived (Serra 
TABLE 1 The last records of the northern bald ibis in the Middle East and north-east Africa.

\begin{tabular}{lll}
\hline Country & Year & Reference \\
\hline Egypt & 1962 & Goodman \& Meininger (1989) \\
Eritrea & 1997 & Dewhurst (1998) \\
Ethiopia & 1977 & Ash \& Howell (1977) \\
Israel & 1995 & Van den Berg (1995) \\
Saudi Arabia & 1993 & Kirwan (1993) \\
Somalia & 1993 & Ash \& Miskell (1998) \\
Sudan & 1983 & Nikolaus \& Hamed (1984) \\
Yemen & 1993 & Rose \& Taylor (1993) \\
\hline
\end{tabular}

et al., in press). Knowledge of migration routes, flight speeds and stopovers could inform the efforts to re-establish migratory populations (Fritz, 2007).

Here we report results from tracking Syrian ibises between July 2006 and March 2007 using satellite PTTs (platform transmitter terminals).

\section{Methods}

Three adult birds were trapped and fitted with PTTs in June 2006 after 3 years of unsuccessful attempts (Bowden \& Tyler, 2003; Peške, 2005; Serra \& Peške, 2006). Birds were caught just prior to the fledging of their offspring using a clap net set beside a regular drinking point. Each bird was measured, weighed and fitted with a numbered plastic leg ring. Two birds had battery powered tags (Northstar Geotrack, $30 \mathrm{~g}$ ) attached on the lower back by teflon ribbon loops around the legs (Rappole \& Tipton, 1991). One bird had a solar-powered tag (Microwave PTT 100, $12 \mathrm{~g}$ ) attached on the upper back as a backpack with loops around the wings and across the chest (Table 2). Both these harness designs were pre-tested on captive, free flying northern bald ibis (LP, unpubl. data). Each PTT had a VHF transmitter (3.5-5.5 g) attached to allow local movements to be monitored from the ground (Peške et al., 1996). Soon after tagging all three birds resumed foraging and attending their nests and no disturbance to the social cohesion of the group was noted. Both nests belonging to these adults went on to fledge three young each and all birds in the colony foraged together throughout the following 4 weeks prior to migration.
Location data were acquired through Argos (Argos, 2009) and were accepted on the basis of location quality class, travel speed and travel direction. Home range areas were estimated using minimum convex polygons. Land cover and topography were assessed using freely available satellite imagery and digital elevation data (CGIAR-CSI, 2006; Google, 2007). Local volunteers visited one stopover site and we spent 3 weeks at the wintering site making field observations.

\section{Results}

Location data showed that the three tagged birds migrated together, so we regard each acceptable location on the southward migration as representative of the group. The entire colony left the breeding site on 18 July 2006 (the three tagged birds, an untagged adult, three non-breeding subadults and six first year birds). The tagged birds flew south across the eastern desert of Jordan, along the western coastal plain of Saudi Arabia, following the line of the Asir Mountains towards the south, and after 9 days reached north-west Yemen where they staged for 18-19 days (Fig. 1). Whilst there, the birds spent most days (at least 9; 9 days being unaccounted for) in a c. $45 \mathrm{~km}^{2}$ area of irrigated fields on the coastal plain. The birds roosted nearby for 2 nights but for most nights $(8-17)$ they commuted $19 \mathrm{~km}$ away to an area of fields $2 \mathrm{~km}$ from a small town. Local observers saw a group of six birds as they left their roost in this area on 3 August 2006 (A.R. Al Eryani, pers. comm.). At least one bird roosted $28 \mathrm{~km}$ to the south of there on 1 night, and 6 nights were unaccounted for.

The birds then flew south, crossing the Red Sea (probably at or near the Bab-el-Mendab Straits) into Eritrea or Djibouti and on into Ethiopia to a wintering site c. $75 \mathrm{~km}$ north-east of Addis Ababa. They remained there until 9 February 2007. The southward migration lasted 32 days, including 18 or 19 days stopover in Yemen, and the distance travelled was c. 3,150 km.

Over winter the birds used a small area of c. $35 \mathrm{~km}^{2}$ for the entire period, with the area used increasing slightly over time (Serra et al., 2007b). Field observations confirmed that the three tagged birds and one other adult reached the site but no subadults or first years. All four birds stayed close together when foraging and loafing, and roosted together

TABLE 2 Details of the tagging of three northern bald ibises (Figs 1-3). Tag weight for \% calculation includes VHF transmitter and harness.

\begin{tabular}{llllllll}
\hline Bird ID & Sex & $\begin{array}{l}\text { Tagging } \\
\text { date }(2006)\end{array}$ & $\begin{array}{l}\text { Body } \\
\text { weight }(\mathrm{g})\end{array}$ & Tag type & $\begin{array}{l}\text { \% body } \\
\text { weight }\end{array}$ & $\begin{array}{l}\text { Harness } \\
\text { type }\end{array}$ & Tag cycle \\
\hline 66327 & Female & 1 June & 1,470 & Solar & c. 1.2 & Back pack & $12 \mathrm{~h} \mathrm{on} 44 \mathrm{~h} \mathrm{off}$ \\
41881 & Female & 4 June & 1,350 & Battery & c. 2.5 & Rappole & $9 \mathrm{~h}$ on $72 \mathrm{~h} \mathrm{off}$ \\
41880 & Male & 11 June & 1,540 & Battery & c. 2.1 & Rappole & 9 h on 72 h off \\
\hline
\end{tabular}




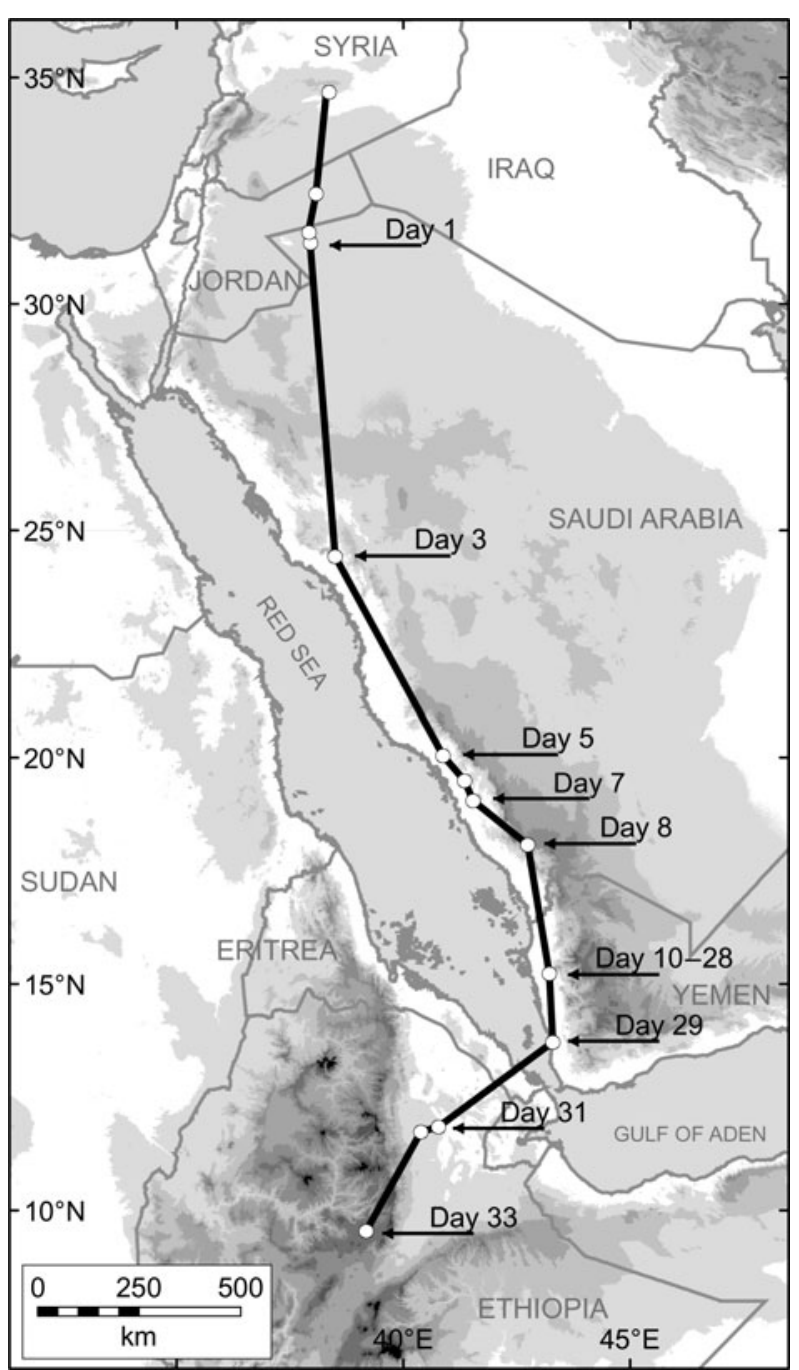

Fig. 1 The southward post-breeding migration route of northern bald ibis breeding in Syria. Day 1 was 18 July 2006. Subsequent dates show the relative speed of migration for each leg. Shading indicates geographical relief.

each night in a large Eucalyptus grandis. The wintering site was in gently undulating low intensity cultivation (wheat, tef, barley and oats) and pastureland with scattered acacia trees, at a mean altitude of $2,750 \mathrm{~m}$. A more detailed description of the wintering site and observations of the birds' behaviour there are given by Serra et al. (2007b).

The three tagged birds separated during the northward migration (Fig. 2). Two left the wintering site on 10 or 11 February 2007 and the third on 12 February. All three flew along the west of the Red Sea stopping at sites in northern Eritrea and southern Sudan. The trailing bird stopped at sites close to those that the leading pair had stopped at 2 days earlier. All three birds regrouped on the south Sudanese coast and crossed the Red Sea together into Saudi Arabia. The c. $300 \mathrm{~km}$ crossing included the only instance of nocturnal flight recorded during the entire study. All three birds stopped for several days near their landfall but again separated for the remainder of the migration. A male arrived back at the colony on 25 February (c. 16 days journey time), a female on 28 February (c. 19 days journey time). The second female spent c. 12 days in southern Saudi Arabia then stopped in the border regions of Saudi Arabia and Jordan, before arriving in Syria on 9 March. She spent 3 days at a site $60 \mathrm{~km}$ to the west (an old colony site) before reaching the colony 28 days after leaving Ethiopia. The return route was just over $3,000 \mathrm{~km}$.

The untagged adult did not return to the Syrian colony and is assumed to have died at the wintering site or en route north. Four other birds (all subadults) returned to the colony in April 2007 and must have wintered elsewhere.

\section{Discussion}

The route, the staging areas and the wintering site used by the tagged ibises are notably consistent with historical records (Fig. 3), with almost all documented locations in the Red Sea region visited or passed by (Table 3). Northeast African and Yemeni records caused some to speculate that there may have been a breeding population there (Guichard, 1950; Smith, 1955) and there were also rumours of a colony in Somalia (Stanton, 1997). However, Smith (1970) eventually decided that his Eritrean records were probably of Turkish birds from Birecik and our observations further weaken the case for recent breeding this far south. Others have assumed that the last records in Yemen were of Turkish birds (Brooks et al., 1987) but at least some may have been from Syria.

Few of the stopover, staging or wintering sites are within or near existing conservation areas. An overnight stop made in north-east Ethiopia lies within the Mille Sardo Wildlife Reserve just north of Yangudi Rassa National Park; and sites used in central Eritrea are near the Nakfa and Yob Wildlife Reserves. Several sites are in or near existing Important Bird Areas (Hima al Fiqrah and Rayadh Escarpment Special Nature Reserve in Saudi Arabia; Al Kadan and the Al Mukha-Al Khawkhah Important Bird Area (IBA) in Yemen; Gulf of Zula in central Eritrea; Birdlife International, 2007). Whilst having no protected status per se, IBA designation can help promote conservation of a site. The wintering site in Ethiopia qualifies as an IBA and should be designated as such. The ibises lived in close proximity to humans and were dependent on farmed habitats, and thus may be vulnerable to intensification of land use or degradation because of overexploitation and drought. Pesticides have been implicated in declines of northern bald ibis elsewhere (Parslow, 1973) and although cost currently prohibits their use in this area this situation could change and needs to be monitored. At both breeding and wintering grounds socio-economic issues are crucial to the birds' survival. The habitat used is strongly modified by the activities of Bedouin pastoralists in Syria and agro-pastoralists in 

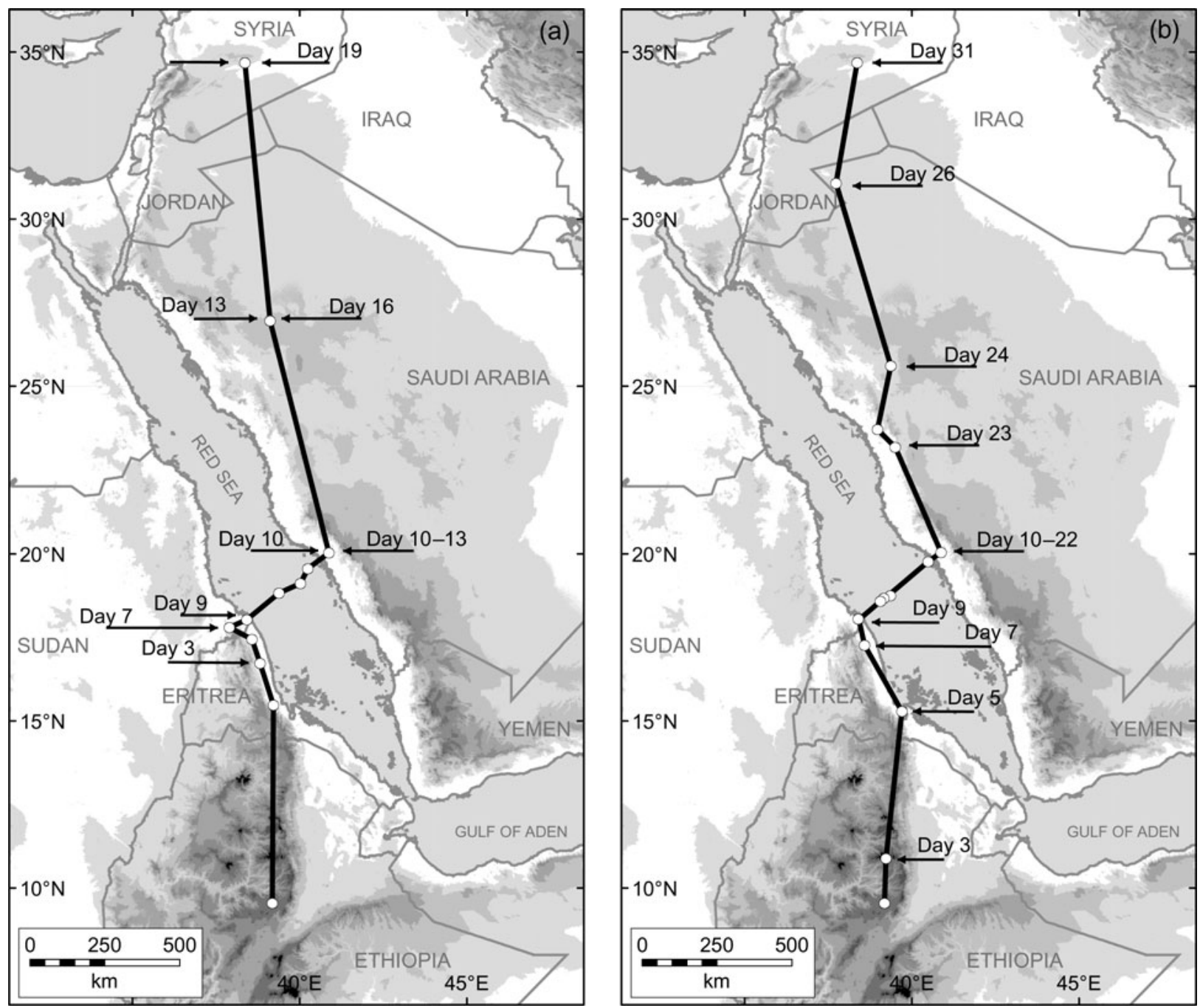

FIG. 2 The northward pre-breeding migration route of (a) ID41880 (left-hand days) and ID41881 (right-hand days), and (b) ID66327. Day 1 was either 10 or 11 February 2007. All three birds crossed the Red Sea on the same day. Shading indicates geographical relief.

Ethiopia. The extent to which human livelihoods can continue to be sustained by natural resources will determine the future availability of suitable ibis habitat in both these areas.

The migration route crossed several countries with high per capita densities of firearm ownership (Small Arms Survey, 2007) and strong hunting cultures. The site where the birds made landfall in Saudi Arabia, Al Lith, is a migration bottleneck and Arabian falconers trap migrant falcons here (G. Welch, pers. comm.). Presumably, this will place other species using the area at risk. Conservation work at $\mathrm{Al}$ Lith may well have benefits for more than just ibises.

Explaining the difference in southward and northward routes is difficult. Prevailing wind directions (Meyburg et al., 2003) and availability of food at staging areas (Fujita et al. 2004) may be responsible. The birds appeared to be dependent on staging areas in Yemen and Eritrea, although less so in Eritrea, presumably because of a winter spent feeding in Ethiopia. Past observations of ibises in Eritrea in
January tied their presence to local rainfall and hence food availability (Smith, 1970). The most unexpected feature, however, was the long sea crossing, a risky strategy notably avoided by other larger migrants (Meyburg et al., 2002).

The results showed a significant difference in migration behaviour between adults and young birds, the two groups appearing to separate at an early stage. Because only six birds were seen in Yemen in autumn it seems that young birds were already left behind further north. The speed of migration (c. $256 \mathrm{~km}$ per day for the first 9 days) may have been too fast for juveniles that fledged only 30 days earlier. Searches around the wintering site failed to reveal any other birds (Serra et al., 2007b) and, given this species' social behaviour, it seems unlikely that other ibises were wintering separately nearby. However, more extensive searches should be made in the Ethiopian highlands, in suitable habitat and in the vicinity of historic records. Brief searches at the Yemeni site and enquiries amongst local residents were fruitless (A.R. Al Eryani, pers. comm.). The birds 


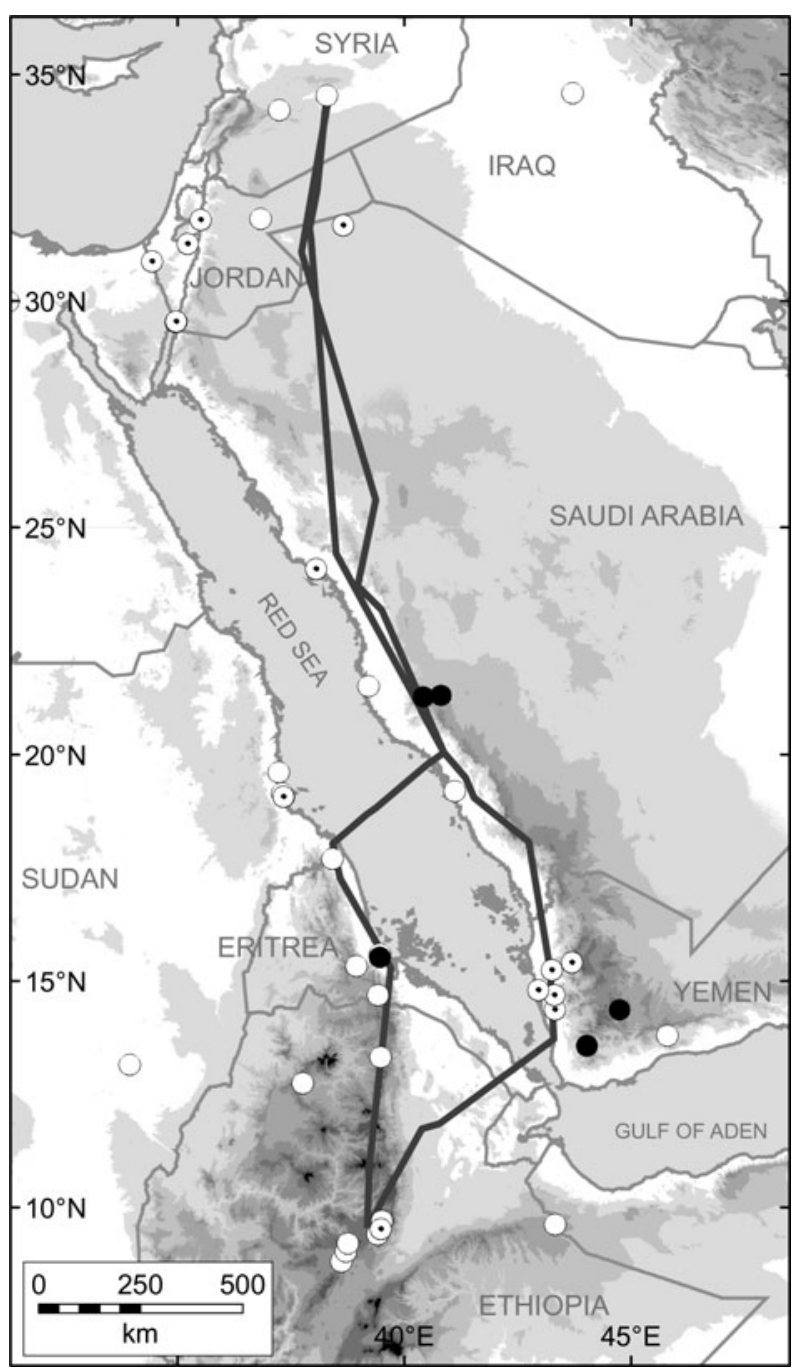

FIG. 3 The position of the current migration route, showing the close correlation with historical records of northern bald ibis in the Red Sea basin. Open circles are records prior to 1960, dotted circles are records for 1960-1989, and filled circles are records since 1989.

stopped briefly at various other places in Saudi Arabia and in southern Yemen but these sites have not been searched. The four untagged birds that returned to Syria were all at least 2 years old, so the six first-year birds are unaccounted for. There are several spring records of northern bald ibis in Saudi Arabia (Baldwin \& Meadows, 1988; Kirwan, 1992), which may relate to returning pre-breeders. There are also summer records from Yemen, with up to eight birds at Ta'izz sewage lagoons in June 1985 (Brooks et al., 1987). Fieldwork within Saudi Arabia and Yemen is needed to search for summering birds and to assess risks at key sites.

Despite efforts, to date there has been no successful reintroduction of fully independent northern bald ibis into the wild (Boehm et al., 2007). The reasons for this are varied but the added complication of migratory behaviour makes the prospect of reintroducing a population in the east seem harder still. Thus, in addition to being the only wild northern bald ibises away from Morocco, the importance of protecting the Syrian birds in situ is further heightened by the desirability of retaining their distinctive migratory behaviour and preventing the loss of this habit and knowledge.

The deteriorating status of the northern bald ibis in Syria in the 2oth century parallels the degradation of the Syrian steppe over this time, resulting in a substantial loss of biodiversity (Serra et al., 2008). But, as this research demonstrates, in common with many migratory species, the survival of this relict ibis population depends on conservation actions in up to six other countries, as well as in the breeding area. Nonetheless, this is an important flagship species in Syria, already resulting in increased ecological and conservation awareness in the country, with the potential for extension into other range states.

Since this work was undertaken the colony size has remained at two breeding pairs. Location data from one of the ibises during migrations in 2007-2008 and 2008-2009 showed it using the same southward migration route, Yemeni staging area and Ethiopian wintering site, and again only adults were found at the latter during visits (Wondafrash \& Dellelegn, 2007; G. Serra, pers. obs.). A second southward staging area in southern Saudi Arabia was used in 2008-2009 in addition to the site in Yemen. The partners in this project have succeeded in tagging one juvenile to date, which remained in Syria when the rest of the colony had left and then disappeared c. 50 days after tagging. The dispersal and migratory behaviour of non-breeding birds remains unknown and in urgent need of resolution.

\section{Acknowledgements}

We are grateful to the Desert Commission, Syria, which is responsible for the protection of this colony (formerly under the Ministry of Agriculture and Agrarian Reform), in particular the Director Ali Hamoud and the former Director of Al Talila Reserve, Abdulkhlek Abdullah Assaad. In Syria we also thank Sultan Naglan, Faraj Bustan and Sulaiman Jukhaidem at Al Talila Reserve, and Dr Akram Darwish and Osama Al Nouri of the Syrian Society for the Conservation of Wildlife. We thank Ibrahim Khader, Sharif Jbour and staff of the BirdLife Middle East office, Dr A.R. $\mathrm{Al}$ Eryani, Omar Al Saghier and colleagues in Yemen, and the staff of the Ethiopian Wildlife Society. We also thank Mike Jordan, Richard Porter and Keith Betton. Funds were provided by the RSPB, the National Geographic Society, the African-Eurasian Waterbird Agreement, Chester Zoo, the African Bird Club/Wildwings Conservation Award and the Ornithological Society of the Middle East. Paul Buckley, Chris Bowden, Ken Smith, Paul Donald and Debbie Pain provided advice, support and valuable comments on this article as did two anonymous referees. 
TABLE 3 Proximity of locations and routes used by Syrian ibises to historical records. The precision of distances from the flight paths (Figs 1-3) to historical data is given as no lower than $10 \mathrm{~km}$ due to uncertainty of the exact flight paths.

\begin{tabular}{llcll}
\hline Country & Historic site & $\begin{array}{l}\text { Distance } \\
(\mathrm{km})\end{array}$ & Year & Reference \\
\hline Saudi Arabia & Yanbu & 60 & 1986 & Baldwin \& Meadows (1988) \\
& Taif & 130 & 1993 & Kirwan (1993) \\
Yemen & Al Kadan & 0 & 1984 & Arooks et al. (1987) \\
& Al Mansuriyah & 15 & 1985 & Harvey (1993) \\
& Ta'izz & 200 & 1993 & Ash \& Howell (1977) \\
Ethiopia & Chacha & 35 & 1977 & Guichard (1950) \\
& Sululta & 60 & 1946 & Guichard (1950) \\
& Debre Birhan & 40 & 1947 & Elliott (1877) \\
& Hintalo & $25-50$ & pre-1877 & Elliott (1877) \\
Eritrea & Woggara & $140-160$ & pre-1877 & Dewhurst (1998) \\
& Senafe & $15-50$ & pre-1877 & Smith (1955) \\
& Hirghigo & 40 & 1997 & Smith (1955) \\
& Karora & 30 & 1952 & Smith (1955) \\
\hline
\end{tabular}

\section{References}

Anonymous (1985) Birds in Yemen October 1985. Newsletter of the Ornithological Society of North Yemen, October 1985, 8.

Argos (2009) Http://www.argos-system.org/ [accessed 17 March 2009].

Arihan, O. (1998) Recent information on the occurrence of the northern bald ibis Geronticus eremita in Turkey. Turna, 1, 10-15.

Ash, J.S. \& Howell, T.R. (1977) The bald ibis or waldrapp Geronticus eremita in Ethiopia. Bulletin of the British Ornithologists' Club, 97, 104.

Ash, J.S. \& Miskell, J.E. (1998) Birds of Somalia. Pica Press, Sussex, UK.

Baldwin, P.J. \& Meadows, B.S. (1988) Birds of Madinat Yanbu Al Sinaiyah and its Hinterland. Royal Commission for Jubail and Yanbu, Riyadh, Saudi Arabia.

BirdLife International (2000) Threatened Birds of the World. Lynx Edicions, Barcelona, Spain and BirdLife International, Cambridge, UK.

BirdLife International (2007) Species factsheet: Geronticus eremita. BirdLife International, Cambridge, UK. Http://www.birdlife.org/ datazone/species/index.html?action $=$ SpcHTMDetails.asp\& sid $=3791 \& \mathrm{~m}=0$ [accessed 29 June 2007]

Boemm, C., Bowden, C.G.R., Jordan, M. \& King, C. (eds) (2007) Northern Bald Ibis Conservation and Reintroduction Workshop, Vejer, Spain. RSPB, Sandy, UK.

Bowden, C.G.R., Aghnaj, A., Smith, K.W. \& Ribi, M. (2003) The status and recent breeding performance of the critically endangered northern bald ibis Geronticus eremita population on the Atlantic coast of Morocco. Ibis, 145, 419-431.

Bowden, C.G.R. \& Tyler, G.A. (2003) Report on a Visit to Syria 12-25 June 2003 Attempting to Catch and Satellite Tag Two Northern Bald Ibis. Unpublished Report. RSPB, Sandy, UK.

Brooks, D.J., Evans, M.I., Martins, R.P. \& Porter, R.F. (1987) The status of birds in North Yemen and the records of the OSME expedition in autumn 1985. Sandgrouse, 9, 4-66.

CGIAR-CSI (2006) The CGIAR Consortium for Spatial Information. Http://srtm.csi.cgiar.org [accessed June 2006].

COLla R, N.J. \& STUART, S.N. (1985) Threatened Birds of African and Related Islands. ICBP, Cambridge, UK and Gland, Switzerland.
Dewhurst, C. (1998) Sighting of waldrapp Geronticus eremita in Eritrea near the Red Sea Coast. Scopus, 20, 57.

Elliot, D.G. (1877) Review of the Ibidinae, or subfamily of the ibises. Proceedings of the Zoological Society of London, 45, 477-510.

Fritz, J. (2007) The Scharnstein waldrapp ibis migration project after 4 years: birds leave the microlight behind. In Northern Bald Ibis Conservation and Reintroduction Workshop, Vejer, Spain (eds C. Boehm, C.G.R. Bowden, M. Jordan \& C. King), pp. 67-76. RSPB, Sandy, UK.

Fujita, G., Guan, H.L., Ueta, M., Goroshio, O., Krever, V., OzAKI, K. et al. (2004) Comparing areas of suitable habitats along travelled and possible shortest routes in migration of white-naped cranes Grus vipio in East Asia. Ibis, 146, 461-474.

Goodman, S.M. \& Meininger, P.L. (1989) The Birds of Egypt. Oxford University Press, Oxford, UK.

Google (2007) Http://maps.google.co.uk [accessed April 2007].

Guichard, K.M. (1950) A summary of the birds of the Addis Abeba region, Ethiopia. Journal of the East Africa Natural History Society, 19, 154-181.

Harvey, D. (1993) Bald ibises at Taiz. Yemen Ornithological Society Newsletter, 1993, 3.

Hirsch, U. (1979) Studies of west Palearctic birds. 183 bald ibis. British Birds, 72, 313-325.

IUCN (2008) 2008 IUCN Red List of Threatened Species. IUCN, Gland, Switzerland. Http://www.iucnredlist.org [accessed 17 March 2009].

Kirwan, G. (1992) Around the region. Bulletin of the Ornithological Society of the Middle East, 29, 43.

Kirwan, G. (1993) Around the region. Bulletin of the Ornithological Society of the Middle East, 30, 45.

Kumerloeve, H. (1984) The waldrapp Geronticus eremita (Linnaeus, 1758): historical review, taxonomic history and present status. Biological Conservation, 30, 363-373.

Meyburg, B.-U., Matthes, J. \& Meyburg, C. (2002) Satellitetracked lesser spotted eagle avoids crossing water at the Gulf of Suez. British Birds, 95, 372-376.

Meyburg, B.-U., Paillat, P. \& Meyburg, C. (2003) Migration routes of steppe eagles between Asia and Africa: a study by means of satellite telemetry. The Condor, 105, 219-227. 
Nikolaus, G. \& Hamed, D.M. (1984) Distinct status changes of certain Palearctic migrants in the Sudan. Scopus, 8, 36-38.

PARSLOW, J.R.F. (1973) Organochlorine insecticide residues and food remains in a bald ibis Geronticus eremita chick from Birecik, Turkey. Bulletin of the British Ornithologists' Club, 93, 163-166.

PEšKe, L. (2005) Report on Northern Bald Ibis Satellite Tagging Fieldwork in Syria, June 2005. Unpublished Report. RSPB, Sandy, UK.

Peške, L., Bobek, M., Pojer, F., Šimek, J. \& Mrlík, V. (1996) Satellite and VHF radio-tracking of black storks migrating from Europe to Africa. Argos Newsletter, 51, 7.

Rappole, J.H. \& Tipton, A.R. (1991) New harness design for attachment of radio transmitters to small passerines. Journal of Field Ornithology, 62, 335-337.

Rose, P.M. \& TA Ylor, V. (1993) Western Palearctic and South-West Asia Waterfowl Census 1993. International Waterfowl and Wetlands Research Bureau, Slimbridge, UK.

SAfriel, U.N. (1980) Notes on the extinct population of the bald ibis Geronticus eremita in the Syrian desert. Ibis, 122, 82-88.

Serra, G., Abdallah, M. \& Al Qaim, G. (2008) Feeding ecology and behaviour of last surviving middle eastern northern bald ibises breeding in the Syrian steppe. Zoology in the Middle East, $43,55-68$.

Serra, G., Abdallah, M., Assaed, A., Abdallah, A., Al Qaim, G., FAYED, T. et al. (2003) Discovery of a relict breeding colony of northern bald ibis Geronticus eremita in Syria. Oryx, 38, 106-108.

Serra, G., Kanani, A., Al Qaim, G., Abdallah, S.M. \& Peške, L. (2007a) Northern bald ibis conservation efforts in Syria 2002-2006: results and lessons learned. In Northern Bald Ibis Conservation and Reintroduction Workshop, Vejer, Spain (eds C. Boehm, C.G.R. Bowden, M. Jordan \& C. King), pp. 36-42. RSPB, Sandy, UK.

Serra, G. \& PešKe, L. (2006) Coordinating Protection Efforts of Breeding Northern Bald Ibises Geronticus eremita in Palmyra (Syria) and Trapping/Satellite Tagging Three Individuals. Unpublished Report. RSPB, Sandy, UK.

Serra, G., PešKe, L., Abdallah, M.S., al Qaim, G. \& Kanani, A. (in press) Breeding ecology and behaviour of the last wild oriental northern bald ibises in Syria. Journal of Ornithology.
Serra, G., Peške, L. \& Wondafrash, M. (2007b) First survey of eastern northern bald ibis Geronticus eremita wintering on the Ethiopian highlands: field mission report 14 November1 December 2006. In Northern Bald Ibis Conservation and Reintroduction Workshop, Vejer, Spain (eds C. Boehm, C.G.R. Bowden, M. Jordan \& C. King), pp. 84-99. RSPB, Sandy, UK.

Small Arms Survey (2007) The Small Arms Survey 2007: Guns and the City. Cambridge University Press, Cambridge, UK.

Sмiтн, K.D. (1955) Recent records from Eritrea. Ibis, 97, 65-80.

Sмith, K.D. (1970) The waldrapp Geronticus eremita (L.). Bulletin of the British Ornithologists' Club, 90, 18-24.

Stanton, D. (1997) Bald ibis update. The Lammergeier, 11, 1.

VAn den Berg, A.B. (1995) WP reports. Dutch Birding, 17, 171-175.

WelCh, G. \& WelCh, H. (2004) Movements of the eastern population of northern bald ibis Geronticus eremita in the Middle East. IAGNBI Newsletter, 3, 66-72.

Wondafrash, M. \& Dellelegn, Y. (2007) Bald Ibis Survey in Abichuna Gne-a District, Doyo Dawe Farmers' Association, Ethiopia: 26-29 October 2007. Unpublished EWNHS Report. Ethiopian Wildlife and Natural History Society, Addis Ababa, Ethiopia.

\section{Biographical sketches}

JeREMy Lindell focuses on tropical forest conservation in West Africa and Asia, managing surveys, threatened species research, monitoring and ecosystem services research. GianlUCA SERRA's research interests focus on applied conservation, biodiversity monitoring, protected area management and local community participation. He has been involved in the northern bald ibis conservation project in Syria since 2002. LUвомIR PEŠKe studies raptors, storks and bustards. He specializes in using telemetry to track wildlife, pioneering the combined use of UHF and VHF technology to track long distance migrants. Mahmud S. Abdallah and Ghazy aL QAim are rangers at Al Talila Reserve and Dr Ahmed KANANi is the Director of Desert Commission. Mengistu Wondafrash is the Biodiversity Conservation Team Leader \& Programmes Director of the Ethiopian Wildlife and Natural History Society and manages conservation projects throughout Ethiopia, particularly for threatened species such as the white-winged flufftail. 